\title{
Plant ferredoxin-like protein (PFLP) exhibits an anti-microbial ability against soft-rot pathogen Erwinia carotovora subsp. carotovora in vitro and in vivo
}

\author{
Hsiang-En Huang ${ }^{a}$, Mang-Jye Ger ${ }^{c}$, Chao-Ying Chen ${ }^{b}$, Mei-Kuen Yip ${ }^{a}$, \\ Mei-Chu Chung ${ }^{\text {a }}$, Teng-Yung Feng ${ }^{a}, *$ \\ ${ }^{a}$ Institute of Plant and Microbial Biology, Academia Sinica, Taipei 115, Taiwan \\ ${ }^{\mathrm{b}}$ Department of Pathology and Microbiology, National Taiwan University, Taipei 106, Taiwan \\ ${ }^{\mathrm{c}}$ Department of Life Science, National University of Kaohsiung, Kaohsiung 811, Taiwan
}

Received 23 May 2005; received in revised form 23 December 2005; accepted 3 January 2006

Available online 6 February 2006

\begin{abstract}
The anti-microbial protein was frequently used to control the plant bacterial disease. In this study, it was investigated that the anti-microbial activity of recombinant plant ferredoxin-like protein (PFLP) both in vitro and in vivo. The in vitro assay demonstrated that PFLP produced by transformed Escherichia coli exhibited an anti-microbial activity against several bacteria strain including E. coli, Erwinia carotovora and Pseudomonas syringae. The effectiveness of this anti-microbial activity was depending on the $\mathrm{FeSO}_{4}$ that was applied in the cultivated medium. PFLP lost its anti-microbial activity when it was mutated in the 86th cysteine residue that responding for iron binding. Besides, soft-rot symptom of tobacco plants infected by E. carotovora was reduced by application of recombinant PFLP. Transgenic tobacco ectopically over expressing PFLP in the cytoplasm protected plant from the infection of $E$. carotovora during the initial stage. These results indicate that PFLP is an anti-microbial protein that might be able to control the plant diseases via reducing the growth of bacterial pathogen.
\end{abstract}

(C) 2006 Elsevier Ireland Ltd. All rights reserved.

Keywords: Plant ferredoxin-like protein (PFLP); Iron competition; Erwinia carotovora subsp. carotovora; Anti-microbial ability

\section{Introduction}

Ferredoxin (Fd) functions in fundamental metabolism such as photosynthetic electron transfer proteins, nitrate reduction, and carbon-sulfur metabolism [1]. At least six different $\mathrm{Fd}$ isoforms from various green and nongreen tissues have been described so far. They are different in both amino acid sequences and biochemical characteristics from heterotrophic sources [2-6]. Fd I is encoded by an intron-less single-copy gene and exists in the photosynthetic tissues of plant. In recently study, it has been reported that sweet pepper Fd I-like protein (PFLP) was involved in the plant defense mechanism [7]. Transgenic plants over expressing pflp gene in tobacco, orchid and rice exhibited a highly disease resistance against to

\footnotetext{
* Corresponding author. Tel.: +88622652 1867; fax: +88622782 7954 . E-mail address: mpmi224@gate.sinica.edu.tw (T.-Y. Feng).
}

infection of bacterial pathogen including Erwinia carotovora, Pseudomonas syringa and Xanthomonas oryza [8-10].

Fd I contains several prosthetic iron-sulfur clusters usually. It can be of the $[2 \mathrm{Fe}-2 \mathrm{~S}],[4 \mathrm{Fe}-4 \mathrm{~S}]$, or [3Fe-4S] variety and has reduction potentials ranging from -600 to $+200 \mathrm{mV}$ [11]. The cluster irons are bridged by inorganic sulfur atoms and are ligated to the polypeptide backbone by the thiolate side chains of cysteine residues $[12,13]$. For example, the Fe identified from Anabaena has four cysteines are present in C41, C46, C49, and C79. In the peptide sequence of PFLP, three cysteine residues exist at 86th, 91 th and 94 th in the [2Fe-2S] domain respectively [14]. The other domain is casein kinase II (Ck2) phosphorylation site that containing the general consensus sequence $\mathrm{S} / \mathrm{TXXD/E}$. It locates in residues from 136 to 139th in carboxyl-terminal region of PFLP [7]. Post-translation regulation of protein by CK2 kinase would help protein to destabilize alpha helices and to counteract caspase cleavage $[15,16]$. It is uncertain that which domain of iron-sulfur clusters or Ck2 phosphorylation site of PFLP plays an important role in the plant defense. 
Iron competition is an efficient strategy to protect plant from pathogen infection because iron nutrition would influence the microbial community structure in host [17]. For example, the iron-chelator such as lactoferritin [18-22] and siderophore [2325 ] was used to control the plant disease. In this study the antimicrobial activity of recombinant PFLP and its mutant were studied in vitro. The symptom inhibiting ability of recombinant PFLP was also investigated in the mesophyll space of wild type tobacco leaf. Furthermore, the transgenic tobacco ectopically over expressing PFLP in the cytoplasm was inoculated with $E$. carotovora to investigate the anti-microbial activity of PFLP in vivo.

\section{Materials and methods}

\subsection{Plasmid construction}

The signal-peptide truncated $p f l p$ gene (d-pflp) was amplified from the genomic DNA of sweet pepper by polymerase chain reaction (PCR) with the following primers: B5-PFLP: 5'-CGG GAT CCC G-AT GGC TTC ATA CAA AGT GAA ACT ACT-3', and S3-PFLP: 5'-CGA GCT CGT T-AG CCC ACG AGT TCT GCT TCT-'3. The d-pflp-GC gene was amplified from d-pflp by PCR with the following primers: B5PFLP: 5'-CGG GAT CCC G-AT GGC TTC ATA CAA AGT GAA ACT ACT-3', and S3-PFLP-GC: GAC AGC ACC TGC CCA GGA ATA AGG AAG. The products of primary PCR were used as $5^{\prime}$ primers to extending the full-length sequence of d-pflp-GC from d-pflp by second PCR with the $3^{\prime}$ primer S3PFLP (CGA GCT CGT T-AG CCC ACG AGT TCT GCT TCT$\left.3^{\prime}\right)$. The d-pflp-A549 gene was amplified from d-pflp by PCR with the following sequence as primers: B5-PFLP: 5'-CGG GAT CCC G-AT GGC TTC ATA CAA AGT GAA ACT ACT3', and S3-PFLP: CGA GCT CGT T-TC C CTC CTC TAATTG GTC-'3 (Fig. 1a). The amplified fragments of d-pflp, d-pflp-GC and d-pflp-A549 were inserted into the bacterial expression vector pQE30 and transformed into Escherichia coli M15.

\subsection{Expression of recombinant PFLP protein}

E. coli M15 harboring the gene of d-pflp, d-pflp-GC or dpflp-A549 was incubated in LB medium (Difco, USA) with $100 \mu \mathrm{g} / \mathrm{ml}$ ampicillin and $25 \mu \mathrm{g} / \mathrm{ml}$ kanamycin at $37^{\circ} \mathrm{C}$ respectively. When the culture reached an absorbance of 0.6 at $A_{600}$, isopropylthio- $\beta$-D-galactoside induction was given to a final concentration of $1 \mathrm{mM}$. Cells were harvested after $4 \mathrm{~h}$ incubation at $37^{\circ} \mathrm{C}$. Protein was purified with Ni-NTA resin spin kit (Qiagen) in native condition according to the manufacturer instruction. The imidazole residue was removed by P6 gel spin column (Bio-Rad) and the eluting product was dialyzed against $10 \mathrm{mM}$ sodium phosphate buffer ( $\mathrm{pH} 7.0$ ). Purified protein was analyzed in $15 \%$ SDS-PAGE.

\subsection{Analysis of PFLP anti-microbial activity in vitro}

Bacterial suspension of E. coli, E. carotovora subsp. carotovora and Pseudomonas syringae pv. syringae were incubated in the NB medium overnight ( $8 \mathrm{~g} / 1$ Nutrient Broth, Difco, USA). Bacterial suspension of them was diluted with sterilized water to $1 \times 10^{4} \mathrm{cfu} / \mathrm{ml}$ and incubated in the $1 / 4 \mathrm{NB}$ medium ( $2 \mathrm{~g} / \mathrm{l}$ Nutrient Broth, Difco, USA) containing different concentrations of purified PFLP $(0.06,0.12,0.24$ and $0.48 \mu \mathrm{M})$ at $28{ }^{\circ} \mathrm{C}$ with shaking at $175 \mathrm{rpm}$ for $36 \mathrm{~h}$.

Bacterial suspension of E. carotovora subsp. carotovora $\left(1 \times 10^{4} \mathrm{cfu} / \mathrm{ml}\right)$ was incubated in the $1 / 4 \mathrm{NB}$ medium containing $0.2 \mu \mathrm{M}$ of PFLP, PFLP-GC and PFLP-A549. The multiplication of bacteria was recorded by spectrophotometer O.D. 600 at following time. PFLP pre-treated with boiling water for $15 \mathrm{~min}$, bovine serum albumin (BSA) and sterilized water were used as the control.

\subsection{Analysis of PFLP anti-microbial activity in iron-defective medium}

Bacterial suspension of E. carotovora subsp. carotovora $\left(1 \times 10^{4} \mathrm{cfu} / \mathrm{ml}\right)$ was incubated in the XCM minimal medium (20 mM NaCl, $0.16 \mathrm{mM} \mathrm{KH}{ }_{2} \mathrm{PO}_{4}, 10 \mathrm{mM}\left(\mathrm{NH}_{4}\right)_{2} \mathrm{SO}_{4}, 10 \mathrm{mM}$ fructose, $5 \mathrm{mMMgSO}_{4}, 1 \mathrm{mMCaCl}_{2}, 0.32 \mathrm{mMK}_{2} \mathrm{HPO}_{4}, 10 \mathrm{mM}$ sucrose, $0.03 \%$ casamino acid) with or without $0.2 \mu \mathrm{Md}$-PFLP at $28{ }^{\circ} \mathrm{C}, 175 \mathrm{rpm}$. Different concentrations of $\mathrm{FeSO}_{4}(0,0.1$ and $0.01 \mathrm{mM}$ ) were added into this XCM medium. The multiplication of bacteria was recorded by spectrophotometer O.D.600.

\subsection{Semi-in vivo anti-microbial activity analysis of PFLP in tobacco leaf}

E. carotovora subsp. carotovora were incubated in the NB medium (Difco, USA) overnight. Bacterial suspension of (a)

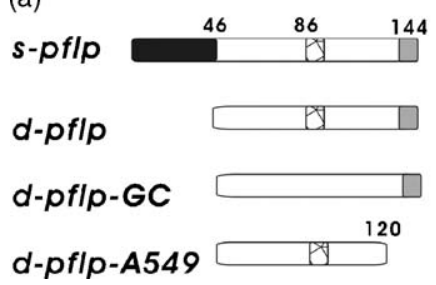

(b)

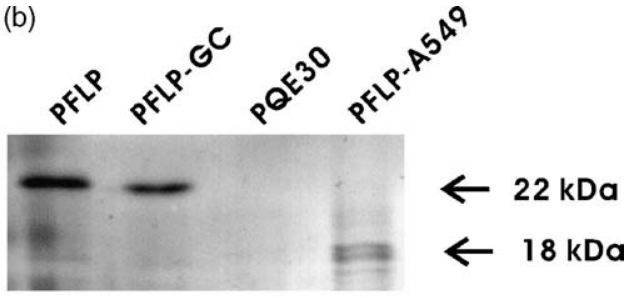

Fig. 1. Recombinant proteins of PFLP, PFLP-GC and PFLP-A549 prepared from transformants of E. coli M15. (a) Schematic diagrams of gene constructs. cDNA of d-pflp, d-pflp-GC and d-pflp-A549 were created by PCR and cloned into the pQE30 vector with restriction enzymes Bam HI and Hind III. (b) Silver staining of purified proteins in SDS-PAGE. Proteins were purified from E. coli M15 harboring pQE30 plasmid that containing cDNA of d-pflp (PFLP), d-pflp-GC (PFLP-GC), d-pflpA549 (PFLP-A549) and vector (pQE30 alone). The purified proteins were separated in 15\% (w/v) SDS-PAGE and visualized by silver staining. 
carotovora subsp. carotovora $\left(1 \times 10^{8} \mathrm{cfu} / \mathrm{ml}\right)$ was mixed with different concentrations of purified PFLP $(0,0.25,0.5,1.0$ and $2.0 \mu \mathrm{M})$ and infiltrated into wild type tobacco leaf, respectively. Photograph was taken 1-day post-inoculation. The soft-rot symptom areas of treated leaves were examined and compared.

\subsection{Generation of d-pflp transgenic tobacco lines}

The PCR product of d-pflp gene was digested with BamHI and SacI, and inserted into the PBI121 vector (Clontech, Palo, CA, USA) to replace the gus gene. This plasmid was transformed into Agrobacterium tumefaciens C58C1 [26]. Transformation of tobacco (Nicotiana tabacum cv. Xanthi) was performed by the standard leaf disc transformation method using kanamycin selection $(100 \mu \mathrm{g} / \mathrm{ml})$ [27]. PCR analysis and DNA gel blotting were used to confirm six independent transformant lines. All transgenic plants grew in a the growth chamber $(16 \mathrm{~h}$ light $/ 8 \mathrm{~h}$ dark at $\left.30^{\circ} \mathrm{C}\right)$. The irradiance of growth chamber is $48 \mu \mathrm{mol} \mathrm{m}{ }^{-2} \mathrm{~s}^{-1}$. Two independent d-pflp transgenic lines were self-fertilized and the seeds were collected.

\subsection{Southern blot analysis}

Genomic DNA was extracted from young leaf tissue by the genomic kit (Qiagen, Germany). The purified DNA was digested with restriction enzymes EcoRI and electrophoretic separation on agarose gels. The Southern blot analysis was performed following the standard procedures [28]. Nylon membranes (Roche, Germany) were hybridized at $65^{\circ} \mathrm{C}$ probing with nptII gene labeled with digoxigenin-11-dUTP (Roche, Germany). After hybridization, membranes were washed under high stringent conditions ( $2 \times \mathrm{SSC}, 0.1 \% \mathrm{SDS})$ and detected by DIG luminescent detection kit (Roche, Germany).

\subsection{Western blot analysis of d-pflp transgenic tobacco}

Total protein of d-pflp transgenic tobacco leaf was extracted $(0.4 \mathrm{~g} / \mathrm{ml})$ in Tris- $\mathrm{HCl}$ buffer $(150 \mathrm{mM} \mathrm{NaCl}, 50 \mathrm{mM}$ Tris $\mathrm{pH}$ 7.5). The concentration of the sample protein was determined with coomassie brilliant blue dye (BioRad). Protein sample $(3 \mu \mathrm{g})$ was subjected to electrophoresis in 15\% SDS-polyacrylamide gel (SDS-PAGE). These gels were either stained with coomassie blue or electro-transferred onto nylon membranes (Roche, Germany) with electro-transfer tank (BioRad). Western blots were done with primary antiserum against PFLP.

\subsection{Soft-rot pathogen inoculated in the d-pflp transgenic tobacco}

Four independent leaves of T2 progenies of d-pflp transgenic tobacco plants (approximately 30 days old) were infiltrated with $100 \mu \mathrm{l}$ bacterial suspension $\left(1 \times 10^{5} \mathrm{cfu} / \mathrm{ml}\right)$ of $E$. carotovora subsp. carotovora by needle. Photograph was taken 1-day post-inoculation.The infected leaves were bruised and mixed with sterilized water $\left(0.2 \mathrm{~cm}^{2} / \mathrm{ml}\right)$. The mixtures were plated and incubated in NB agar plate overnight at $30{ }^{\circ} \mathrm{C}$. The colonies were counted $24 \mathrm{~h}$ after incubation.

\section{Results}

\subsection{Construction and expression of PFLP}

The pflp gene was cloned to the commercial expressing vector pQE30 (Fig. 1a) and transferred into the E. coli M15. In the result, the recombinant protein mainly existed in fractions eluted with $250 \mathrm{mM}$ imidazole when it was purified with $\mathrm{Ni}-$ NTA his 6 spin column under native condition. In the cloning process, the signal peptide of PFLP in the N-terminal region from 1 to 46th resides was removed artificially because it could not be removed by itself in E. coli. The eluent of recombinant PFLP appeared the molecular weight of $22 \mathrm{kDa}$ on the $15 \%$ SDS-PAGE that is the same with native PFLP purified from plant. PFLP-GC is a mutant protein from PFLP whose 86th residue was replaced from cysteine to tryptophan. PFLP-A549 is another mutant protein that was truncated at carbonylterminal region from residues of 120th to 144th. The eluting product of PFLP-GC appeared in the molecular weight of $22 \mathrm{kDa}$, but PFLP-A549 could not result in a simple band in SDS-PAGE (Fig. 1b).

\subsection{In vitro anti-microbial activity analysis of PFLP}

Nutrient broth (NB) medium is good for bacterial growth in vitro but it is too rich in nutrition for anti-microbial activity assay of PFLP. Accordingly, 1/4NB medium that four-fold diluted from NB medium with sterilized water was used for anti-microbial assay of PFLP in vitro. Under this conduction, $0.24 \mu \mathrm{M}$ of PFLP inhibited bacterial growth of E. coli, E. carotovora and $P$. syringae (Fig. 2). The inhibiting activity was increased depending on the dosage of PFLP applied in the 1/4NB medium. Under the same condition, BSA was used as a control that did not show any inhibition activity of bacterial growth.

The anti-microbial activities of two mutated proteins, PFLPGC and PFLP-A549, were examined as well in vitro. As described before, bacterial growth of E. carotovora was inhibited by $0.24 \mu \mathrm{M}$ PFLP $12 \mathrm{~h}$ after incubation. PFLP-A549

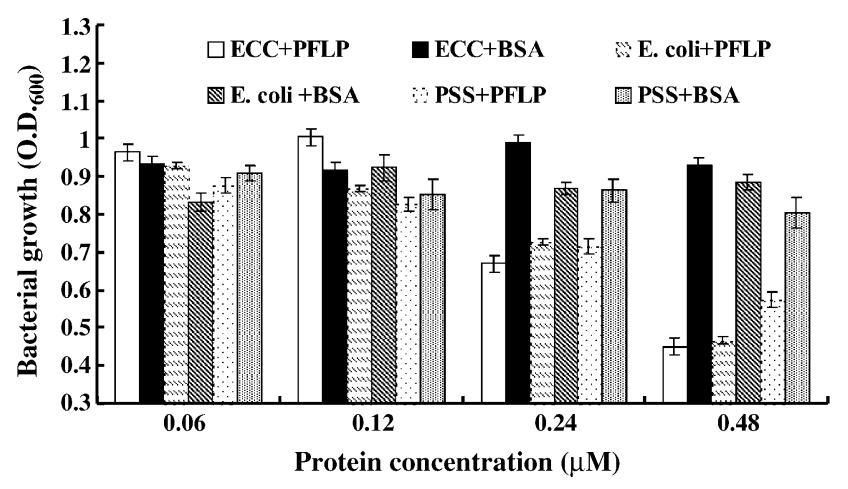

Fig. 2. Anti-microbial activity analysis of PFLP in vitro. Bacterial suspension $\left(1 \times 10^{4} \mathrm{cfu} / \mathrm{ml}\right)$ of E. coli (E.coli), E. carotovora subsp. carotovora $(\mathrm{ECC})$ and P. syringae pv. syringae (PSS) were incubated with various concentration of PFLP $(0.06,0.12,0.24,0.48 \mu \mathrm{M})$ in the $1 / 4 \mathrm{NB}$ medium at $28^{\circ} \mathrm{C}$. The same concentration of bovine serum albumin (BSA) was used as the control. The bacterial multiplications were measured by spectrophotometer O.D. $60036 \mathrm{~h}$ post-inoculation. Vertical error bars denote standard deviation $(n=4)$. 
exhibited its anti-microbial activity as good as PFLP under the same conditions. The bacterial growth inhibited by PFLP and PFLP-A549 was standing for $48 \mathrm{~h}$. On the contrary, PFLP-GC could not inhibit bacterial growth in the concentration of $0.24 \mu \mathrm{M}$ (Fig. 3).

The anti-microbial activity of iron-binding protein is apparent in the iron-defective medium [19-22]. In this study, an iron-defective medium (XCM medium) was used to test the anti-microbial activity of PFLP. Bacterial growth of E. carotovora has been inhibited by $0.2 \mu \mathrm{M}$ of PFLP in the XCM medium until $24 \mathrm{~h}$ after incubation. Excess iron exogenously provided by adding $0.01 \mathrm{mM} \mathrm{FeSO}_{4}$ in the XCM medium has improved the bacterial growth of $E$. carotovora. However, under this condition the improvement of bacterial growth was diminished by the present of $0.2 \mu \mathrm{M}$ of PFLP. The anti-microbial activity of PFLP was broken if the applied $\mathrm{FeSO}_{4}$ in $\mathrm{XCM}$ medium was raised to the concentration of $0.1 \mathrm{mM}$ (Fig. 4). These results demonstrated that the antimicrobial activity of PFLP was depending on the concentration of free iron in the iron-defective medium.

\subsection{Semi-in vivo anti-microbial activity assay of PFLP}

E. carotovora is a bacterial pathogen causing a soft-rot symptom in the tobacco leaf. Different concentrations of PFLP were mixed with the bacterial suspension $\left(1 \times 10^{8}\right)$ and infiltrated into tobacco leaf. The area of soft-rot symptom caused by the bacterial mixture was calculated (Fig. 5). The results showed that symptom caused by the mixture of bacteria suspension and $0.5 \mu \mathrm{M}$ PFLP would be $20 \%$ less compared with the absence of PFLP in the bacterial suspension. More than $50 \%$ area of the soft-rot symptom was reduced by PFLP when the applied concentration of PFLP in the bacterial suspension was raised to $2 \mu \mathrm{M}$.

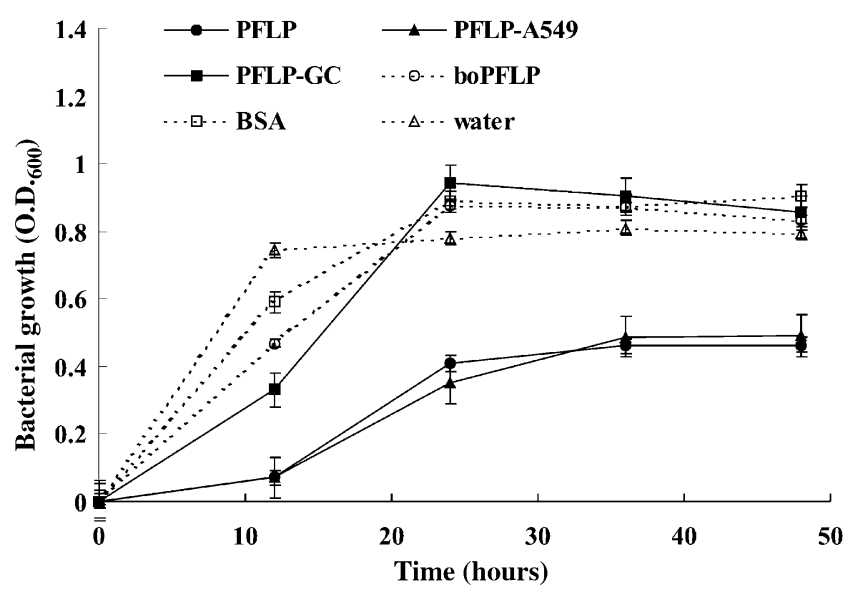

Fig. 3. Anti-microbial activity analysis of mutated PFLP protein in vitro. Bacterial suspensions of E. carotovora subsp. carotovora $\left(1 \times 10^{4} \mathrm{cfu} / \mathrm{ml}\right)$ were incubated with $0.2 \mu \mathrm{M}$ of PFLP, PFLP-GC or PFLP-A549 respectively in the $1 / 4 \mathrm{NB}$ medium. PFLP pre-treated with boiling water for $15 \mathrm{~min}$ (boPFLP), bovine serum albumin (BSA) and sterilized water (water) were used as the controls. The bacterial growth was measured by spectrophotometer O.D.600 at a different time point. Vertical bars represent standard deviations $(n=4)$.

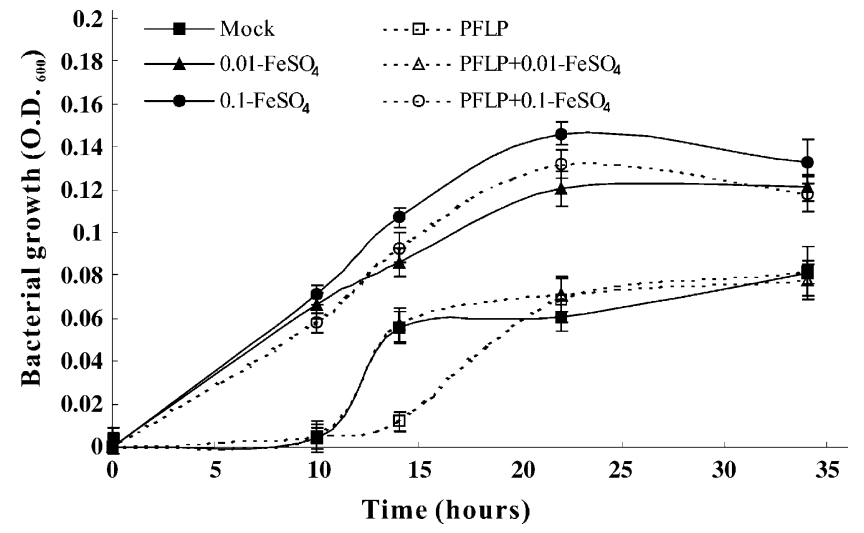

Fig. 4. Anti-microbial activity analysis of PFLP in the iron-defective medium. Bacterial suspension of E. carotovora $\left(1 \times 10^{4} \mathrm{cfu} / \mathrm{ml}\right)$ was incubated with (PFLP) or without (Mock) $0.2 \mu \mathrm{M}$ PFLP in the XCM medium containing $0 \mathrm{mM}, 0.01 \mathrm{mM}\left(0.01-\mathrm{FeSO}_{4}\right)$ or $0.1 \mathrm{mM} \mathrm{FeSO}_{4}\left(0.1-\mathrm{FeSO}_{4}\right)$, respectively. The bacterial concentrations were measured by spectrophotometer O.D.600. Vertical bars represent standard deviations $(n=4)$.

\subsection{Anti-microbial activity assay of PFLP in vivo}

To analyze the anti-microbial activity of PFLP in vivo, the PFLP was over-expressed in the cytoplasm of transgenic tobacco. The independent d-pflp transgenic lines were analyzed by Southern blot (Fig. 6a). The results of Southern blot showed that genomic DNA isolated from line T-dPFLP138 exhibited two individual bands in 5.2 and $8.3 \mathrm{~kb}$ and only one band in $6.5 \mathrm{~kb}$ from line T-dPFLP9-1. These results indicated that the $\mathrm{d}-$ pflp transgenic lines of T-dPFLP9-1 and T-dPFLP138 were independent lines.

Protein expressing level of PFLP in each transgenic line was compared by Western blot analysis (Fig. 6b). The result showed that protein level of PFLP in transgenic tobacco has 2-3-fold
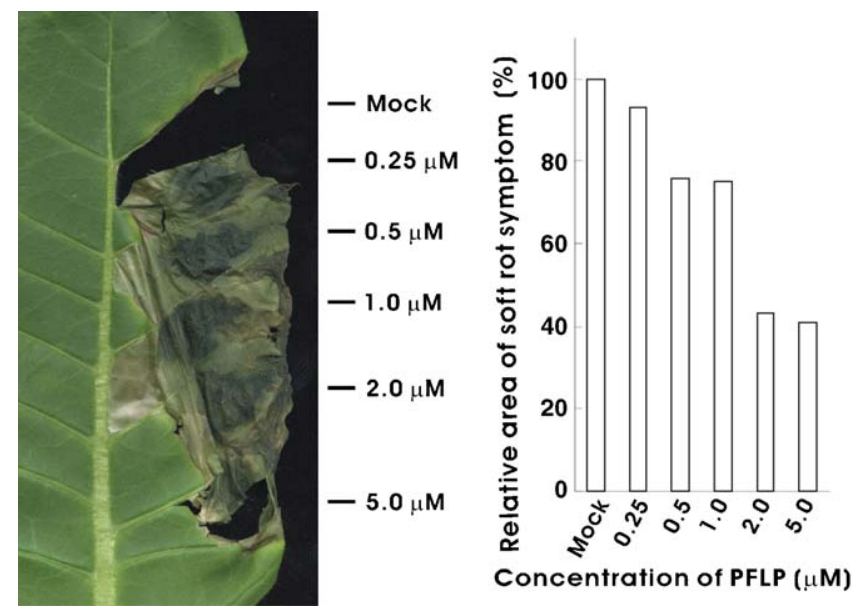

Fig. 5. Anti-microbial activity assay of PFLP in mesophyll space of wild type tobacco. Bacterial suspension of E. carotovora subsp. carotovora $\left(1 \times 10^{8} \mathrm{cfu} /\right.$ $\mathrm{ml})$ was mixed with different concentrations of PFLP $(0,0.25,0.5,1.0,2.0$ and $5.0 \mu \mathrm{M})$ and infiltrated into mesophyll space of wild type tobacco leaf. Symptoms were photographed and relative area of soft-rot symptom was measured at 1-day post infiltration. 
(a)
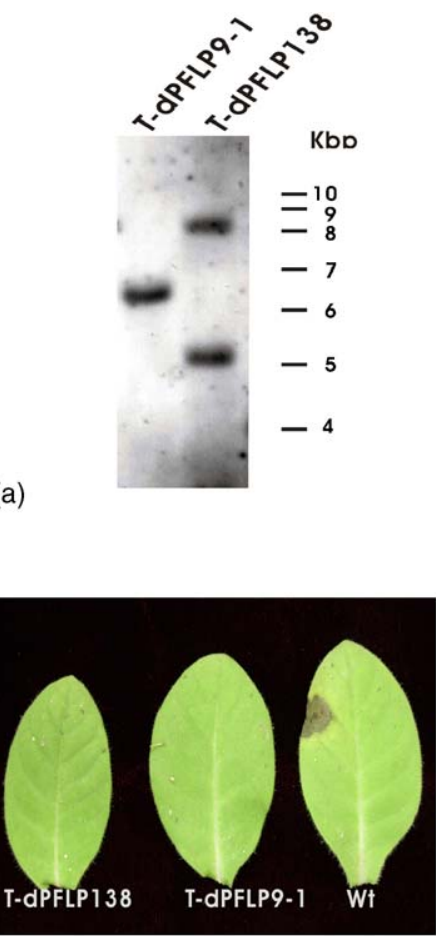

(e)

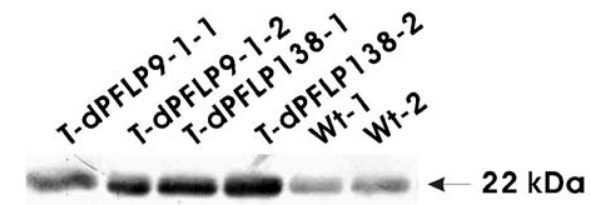

(b)

(c)
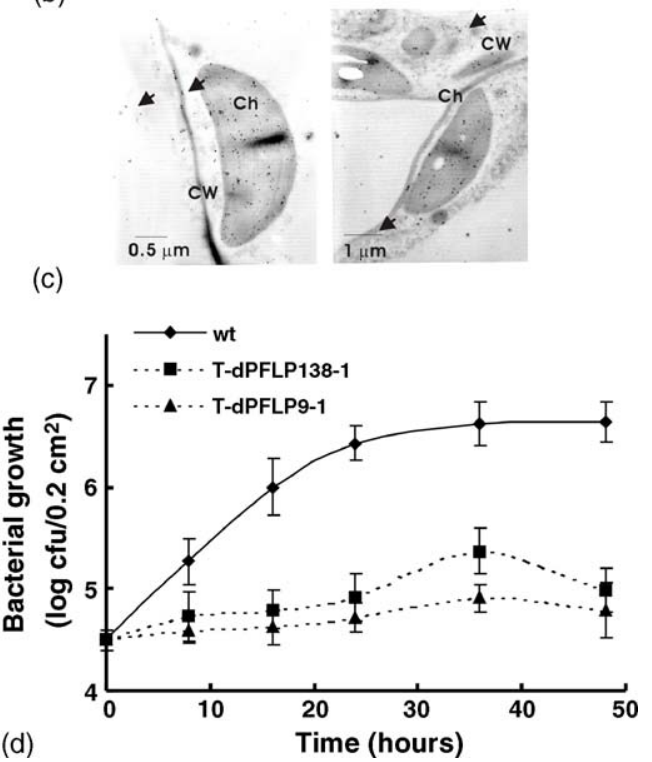

Fig. 6. Soft-rot pathogen inoculated in the d-pflp transgenic tobacco. (a) Southern blot analysis of d-pflp transgenic tobacco. Genomic DNA (15 $\mu \mathrm{g}$ ) of independent d$p f p$ transgenic tobacco lines (T-dPFLP138 and T-dPFLP9-1) were digested with EcoR I. Hybridization was performed with the probe against to $n p t$ II gene at $65{ }^{\circ} \mathrm{C}$. (b) Western blot analysis of d-pflp transgenic tobacco. Total proteins ( $3 \mu \mathrm{g})$ prepared from wild type and d-pflp transgenic tobaccos were analyzed by Western blot probing with antiserum against to PFLP. (c) Electron micrographs of PFLP in d-pftp transgenic tobacco. For immunolocalization of PFLP, ultra thin sections of leaves were incubated with antiserum against to PFLP then detected with gold-conjugated antibodies. The cell wall $(\mathrm{Cw})$ and chloroplast $(\mathrm{Ch})$ of tobacco are labeled in the photograph. Arrows indicated the positions of the $12 \mathrm{~nm}$ gold particles in the cytoplasm. (d) Soft-rot pathogen inoculated in the d-pflp transgenic tobacco. Fully expanded leaves of transgenic (T-dPFLP138, T-dPFLP9-1) and non-transgenic tobacco (Wt) were infiltrated with $100 \mu$ l bacterial suspension of E. carotovora subsp. carotovora $\left(1.0 \times 10^{5} \mathrm{cfu} / \mathrm{ml}\right)$. Photograph was taken 1-day post-inoculation. (e) Bacterial populations in the d-pflp transgenic tobacco. Bacterial were inoculated as described in (d). The bacterial population was detected at successive time points. Vertical bars represent standard deviation $(n=4)$.

increased compared with wild type tobacco (Table 1). Distribution of over-expressed PFLP in transgenic tobacco was monitored in sub-cellular level. The immunogold-labeled PFLP particles were found both in the cytoplasm and chloroplast of transgenic tobacco (Fig. 6c).

The transgenic tobacco was challenged with soft-rot bacterial pathogen E. carotovora $\left(1 \times 10^{5} \mathrm{cfu} / \mathrm{ml}\right)$ that caused a macerating symptom in leaf of wild type tobacco. No symptom was observed, however, after bacterial suspension was inoculated in the transgenic tobacco (Fig. 6d). The bacterial population of $E$. carotovora was inhibited to the level of $1 \times 10^{5} \mathrm{cfu} / \mathrm{ml}$ in the transgenic tobacco, but it was raised to $5 \times 10^{6} \mathrm{cfu} / \mathrm{ml}$ in the wild type tobacco $48 \mathrm{~h}$ after inoculation (Fig. 6e).

Table 1

PFLP levels in $p f p$ transgenic tobacco

\begin{tabular}{ll}
\hline Transgenic line & Protein level (fold) \\
\hline T-dPFLP9-1 & $2.60 \pm 0.41$ \\
T-dPFLP138 & $2.98 \pm 0.36$ \\
Wt & $1.00 \pm 0.21$
\end{tabular}

\footnotetext{
${ }^{\text {a }}$ Protein levels were counted with Western blot. The protein level of PFLP in
} wild type tobacco was defined as 1 .

\section{Discussion}

In previous study, anti-microbial agents could be used to control the plant disease. For example, thionin that is a toxin protein inhibited enzyme activity of bacterial [29], LTP that is cysteine-rich toxic peptides with low-molecular weight [30] and lactoferrin that is an iron-binding protein competing iron with pathogen from the environment [31]. Here we described a recombinant PFLP that has an anti-microbial activity against growth of E. coli, E. carotovora and P. syringa in vitro (Fig. 2). PFLP also inhibits some other un-described bacteria such as $P$. syringae pv. tobaci, $X$. campestris var. vesicatoria, and $X$. campestris var. campestris (data not shown). These results imply that PFLP is bioactive as a high potential anti-microbial agent such as lactoferrin, thionin and LTP that was used for controlling the bacterial plant disease.

Functional domain of PFLP in the anti-microbial activity was studied. The 86th residue encodes an amino acid of cysteine in [2Fe-2S] domain that responding for iron-binding. PFLP mutated in the 86th residue, designated as PFLP-GC, has lost the anti-microbial activity (Fig. 3). This result implies that the iron-binding capability of PFLP was required for anti-microbial activity against the bacterial growth in vitro. Accordingly, if the 
applied concentration of PFLP-GC in cultured medium was increased up to $1 \mu \mathrm{M}$, bacterial growth has been inhibited (data not shown). We suppose that PFLP-GC contains some other putative iron-binding residues such as 91th and 94th besides of 86th residues. Thus application of high-concentration PFLP-GC in cultured medium could inhibit bacterial growth. One the contrary, the carboxyl-terminal region of PFLP in mutant PFLPA549 including the $\mathrm{Ck} 2$ phosphorylation site (S/TXXD/E) was truncated. This mutant remains the anti-microbial activity as well as PFLP has. This result excludes the hypothesis that phosphorylation site of PFLP is necessary for anti-microbial activity. Even the Ck2 phosphorylation site of PFLP is not necessary anti-microbial activity, but it might play an important role in protein stability. Therefore the purified protein of PFLPA549 degrades very soon and could not result a unitary band in the SDS-PAGE (Fig. 1b).

The bacterial pathogen E. carotovora uptakes free iron released from the debris of plant by cell wall-degrading enzymes in the initial period of infection [32]. Iron is an essential nutrition for the bacterial growth and pathogenesis of E. carotovora. For this reason, iron-binding protein was usually used to inhibit bacterial growth in the iron limiting environment [19-22]. In this study, the PFLP has an iron binding domain that essential for anti-microbial activity. The anti-microbial activity of PFLP is depending on the existing concentration of $\mathrm{FeSO}_{4}$ in the iron-defective medium (Fig. 4). Mesophyll space is also an iron-limited environment. The recombinant PFLP has inhibited the soft-rot symptom in the mesophyll space of tobacco leaf (Fig. 5). These results imply that the enrichment of PFLP in mesophyll space of tobacco leaf would inhibit soft-rot symptom cause by E. carotovora.

The resistance inducing in full-length $p f p$ transgenic tobacco was due to activation of HCD [8]. However neither soft-rot symptom nor hypersensitive cell death (HCD)-like necrosis was observed in the d-pflp transgenic tobacco after inoculation of E. carotovora (Fig. 6d). In the initial period of infection, the bacterial multiplication in the d-pflp transgenic tobacco was inhibited (Fig. 6e) but not in the full-length $p f p$ transgenic tobacco. We suppose the different result between d$p f p$ and full-length $p f p$ transgenic tobacco is due to the distribution of the heterologous Fd. In the full-length $p f p$ transgenic tobacco, most abundant PFLP might be travelled to chloroplast as much as they can however the abundant PFLP over expressing in the d-pflp transgenic tobacco was stacked in the cytoplasm only. This difference might result to pathogen more difficult to get iron from debris of d-pflp transgenic tobacco than full-length $p f p$ transgenic tobacco. Therefore, the pathogen would lose the opportunity to cause HCD-like necrosis or soft-rot symptom in the d-pflp transgenic tobacco.

In summary, we demonstrated that PFLP exhibits an antimicrobial activity in vitro and in vivo. The anti-microbial activity of PFLP seems to be depending on the iron-binding capability. Furthermore, abundant PFLP would inhibit symptom caused by bacterial pathogen in the mesophyll space of tobacco leaf. The d-pflp transgenic tobacco over expressing abundant PFLP in the cytoplasm has against infection of $E$. carotovora without induction of HCD-like necrosis.

\section{Acknowledgment}

This work was supported by grants to T.Y. Feng from Academia Sinica, Taiwan, ROC.

\section{References}

[1] J. Meyer, Ferredoxins of the third kind, FEBS Lett. 509 (2001) 1-5.

[2] R.C. Elliott, L.F. Dickey, M.J. White, W.F. Thompson, Cis-acting elements for light regulation of pea ferredoxin 1 gene expression are located within transcribed sequences, Plant Cell 1 (1989) 691-698.

[3] K. Kamide, H. Sakai, K. Aoki, Y. Sanada, K. Wada, L.S. Green, B.C. Yee, B.B. Buchanan, Amino acid sequences of heterotrophic and photosynthetic ferredoxins from the tomato plant (Lycopersicon esculentum Mill.), Photosynth. Res. 46 (1995) 301-308.

[4] T. Matsumura, Y. Kimata-Ariga, H. Sakakibara, T. Sugijama, H. Murata, T. Takao, Y. Shimonishi, T. Hase, Complementary DNA cloning and characterization of ferredoxin localized in bundle-sheath cells of maize leaves, Plant Physiol. 119 (1999) 481-488.

[5] Y. Kimata, T. Hase, Localization of ferredoxin isoproteins in mesophyll and bundle sheath cells in maize leaf, Plant Physiol. 89 (1989) 1193-1197.

[6] Y. Onda, T. Matsumura, Y. Kimata-Ariga, H. Sakakibara, T. Sugiyama, T. Hase, Differential interaction of maize root ferredoxin:NADP ${ }^{+}$oxidoreductase with photosynthetic and non-photosynthetic ferredoxin isoproteins, Plant Physiol. 123 (2000) 1037-1045.

[7] B.V. Dayakar, H.J. Lin, C.H. Chen, M.J. Ger, B.H. Lee, C.H. Pai, D. Chow, H.E. Huang, S.Y. Hwang, M.C. Chung, T.Y. Feng, Ferredoxin from sweet pepper (Capsicum annuum L.) intensifying harpin (Pss) $^{-m e d i a t e d ~ h y p e r-~}$ sensitive response shows an enhanced production of active oxygen species (AOS), Plant Mol. Biol. 51 (2003) 913-924.

[8] H.E. Huang, M.J. Ger, C.Y. Chen, M.K. Yip, A.K. Pandey, T.Y. Feng, A hypersensitive response was induced by virulent bacteria in transgenic tobacco plants overexpressing a plant ferredoxin-like protein (PFLP), Physiol. Mol. Plant Pathol. 64 (2004) 103-110.

[9] C.H. Liau, J.C. Lu, V. Prasad, H.H. Hsiao, S.J. You, J.T. Lee, N.S. Yang, H.E. Huang, T.Y. Feng, W.H. Chen, M.T. Chan, The sweet pepper ferredoxin-like protein ( $p f p$ ) conferred resistance against soft rot disease in Oncidium orchid, Transgen. Res. 12 (2003) 329-336.

[10] K.X. Tang, X.F. Sun, Q.N. Hu, A.Z. Wu, C.H. Lin, H.J. Lin, R.M. Twyman, P. Christou, T.Y. Feng, Transgenic rice plants expressing the ferredoxin-like protein (AP1) from sweet pepper show enhanced resistance to Xanthomonas oryzae pv. oryzae, Plant Sci. 160 (2001) 10351042.

[11] J.M. Moulis, L.C. Sieker, K.S. Wilson, Z. Dauter, Crystal structure of the $2[4 \mathrm{Fe}-4 \mathrm{~S}]$ ferredoxin from Chromatium vinosum: evolutionary and mechanistic inferences for $[3 / 4 \mathrm{Fe}-4 \mathrm{~S}]$ ferredoxins, Prot. Sci. 5 (1996) 1765-1775.

[12] T. Kurihara, H. Mihara, S. Kato, T. Yoshimura, N. Esaki, Assembly of iron-sulfur clusters mediated by cysteine desulfurases, IscS, CsdB and CSD, from Escherichia coli, Biochim. Biophys. Acta 1647 (2003) 303309.

[13] H. Sticht, P. Rosch, The structure of iron-sulfur proteins, Progr. Biophys. Mol. Biol. 70 (1998) 95-136.

[14] J.K. Hurley, A.M. Weber-Main, A.E. Hodges, M.T. Stankovich, M.M. Benning, H.M. Holden, H. Cheng, B. Xia, J.L. Markley, C. Genzor, C. Gomez-Moreno, R. Hafezi, G. Tollin, Iron-sulfur cluster cysteine-toserine mutants of Anabaena $-2 \mathrm{Fe}-2 \mathrm{~S}-$ ferredoxin exhibit unexpected redox properties and are competent in electron transfer to ferredoxin:$\mathrm{NADP}^{+}$reductase, Biochemistry 36 (1997) 15109-15117.

[15] F. Meggio, L.A. Pinna, One-thousand-and-one substrates of protein kinase CK2? FASEB J. 17 (2003) 349-368.

[16] H.G. Kang, D.F. Klessig, Salicylic acid-inducible Arabidopsis CK2like activity phosphorylates TGA2, Plant Mol. Biol. 57 (2005) 541557.

[17] C.H. Yang, D.E. Crowley, Rhizosphere microbial community structure in relation to root location and plant iron nutritional status, Appl. Environ. Microbiol. 66 (2000) 345-351. 
[18] D. Expert, C. Enard, C. Masclaux, The role of iron in plant host-pathogen interactions, Trends Microbiol. 4 (1996) 232-237.

[19] P.P. Ward, O.M. Conneely, Lactoferrin: role in iron homeostasis and host defense against microbial infection, Biometals 17 (2004) 203-208.

[20] D.K. Chong, W.H. Langridge, Expression of full-length bioactive antimicrobial human lactoferrin in potato plants, Transgen. Res. 9 (2000) 7178.

[21] S.M. Choi, O.S. Lee, S.Y. Kwon, S.S. Kwak, D.Y. Yu, H.S. Lee, High expression of a human lactoferrin in transgenic tobacco cell cultures, Biotechnol. Lett. 25 (2003) 213-218.

[22] Y.A. Suzuki, S.L. Kelleher, D. Yalda, L. Wu, J. Huang, N. Huang, B. Lonnerdal, Expression, characterization, and biologic activity of recombinant human lactoferrin in rice, J. Pediatr. Gastroenterol. Nutr. 36 (2003) 190-199.

[23] J.E. Loper, J.S. Buyer, Siderophores in microbial interactions on plant surfaces, Mol. Plant-Microbe Interact. 4 (1991) 5-13.

[24] B.J. Duijff, J.W. Meijer, P.A.H.M. Bakker, B. Schippers, Siderophoremediated competition for iron and induced resistance in suppression of Fusarium wilt of carnation by fluorescent Pseudomonas spp., Netherlands J. Plant Pathol. 99 (1993) 277-289.

[25] S. Buysens, K. Heungens, J. Poppe, M. Höfte, Involvement of pyochelin and pyoverdin in suppression of Pythium-induced damping-off of tomato by Pseudomonas aeruginosa 7NSK2, Appl. Environ. Microbiol. 62 (1996) 865-871.

[26] M. Holsters, D. De Waele, A. Depicker, E. Messens, M. Van Montagu, J. Schell, Transfection and transformation of Agrobacterium tumefaciens, Mol. Gen. Genet. 163 (1978) 182-187.

[27] R.B. Horsch, J.E. Fry, N.L. Hofmannn, D. Eichholtz, S.G. Rogers, R.T. Fraley, A simple and general method for transferring genes into plants, Science 227 (1985) 1229-1231.

[28] J. Sambrook, E.F. Fritsch, T. Maniatis, 2nd ed., Molecular Clone. A Laboratory Manual, vol. E6, Cold Spring Harbor Laboratory Press, Cold Spring Harbor NY, USA, 1989, pp. 9.31-9.57.

[29] M. Pineiro, I. Diaz, P. Rodriguez-Palenzuela, E. Titarenko, F. GarciaOlmedo, Selective disulphide linkage of plant thionins with other proteins, FEBS Lett. 369 (1995) 239-242.

[30] A. Segura, M. Moreno, F. Garcia-Olmedo, Purification antipathogenic activity of lipid transfer proteins (LTPs) from the leaves of Arabidopsis and spinach, FEBS Lett. 332 (1993) 243-346.

[31] M. Malnoy, J.S. Venisse, M.N. Brisset, E. Chevreau, Expression of bovine lactoferrin cDNA confers resistance to Erwinia amylovora in transgenic pear, Mol. Breed. 12 (2003) 231-244.

[32] M.C.M. Pérombelona, Potato diseases caused by soft rot Erwinias: an overview of pathogenesis, Plant Pathol. 51 (2002) 1-4. 